Metallophysics and Advanced Technologies

металофіз. новітні технол.

Metallofiz. Noveishie Tekhnol.

2020, vol. 42, No. 7, pp. 989-996

https://doi.org/10.15407/mfint.42.07.0989

Reprints available directly from the publisher

METALLIC SURFACES AND FILMS

PACSnumbers: 68.35.bd, 68.35.Dv, 68.35.Gy, 81.40.Lm, 81.65.-b, 81.65.Mq, 82.45.Hk

\title{
Structure and Properties of Multicomponent Surface Layers on Steel
}

\section{I. Fedorenkova}

\author{
Oles Honchar Dnipro National University, \\ 72 Gagarin Ave., \\ UA-49010 Dnipro, Ukraine
}

The structure and properties of a multicomponent diffusion layer obtained on steel as a result of joint saturation with boron and other elements (silicon, molybdenum, tungsten) during chemical-thermal treatment (CTT) are investigated in this work. As a result of multicomponent saturation of the steel surface pre-treated by deformation of various intensities (electrolyte plasma, pressing, explosion) a multiphase microstructure of the diffusion layer with higher micromechanical characteristics of the steel surface in comparison with ordinary boron saturation is obtained. As established, the pre-treatment of steel surface at saturation under conditions of a multicomponent CTT accelerates diffusion processes and contributes to the spread of finely dispersed inclusions from refractory boride compounds to a greater depth. This ensures the formation of a multilayer complex coating with unique properties.

Key words: multicomponent saturation, multiphase microstructure, deformation pre-treatment, borides, wear resistance.

У даній роботі досліджено структуру і властивості багатокомпонентного дифузійного шару, одержаного на сталі в результаті спільного насичення Бором та іншими елементами (Силіцій, Молібден, Вольфрам) при хімікотермічній обробці (ХTO). У результаті багатокомпонентного насичення поверхні сталі, попередньо обробленої деформацією різної інтенсивності (електролітна плазма, пресування, вибух), отримана багатофазна мікроструктура дифузійного шару з більш високими мікромеханічними характеристиками поверхні сталі порівняно зі звичайним насиченням Бором. Встановлено, що попередня обробка поверхні сталі при насиченні в умо-

Corresponding author: Lyubov Ivanivna Fedorenkova

E-mail: Luba.Fed@gmail.com

Citation: L. I. Fedorenkova, Structure and Properties of Multicomponent

Surface Layers on Steel, Metallofiz. Noveishie Tekhnol., 42, No. 7: 989-996 (2020), DOI: $10.15407 /$ mfint.42.07.0989. 
вах багатокомпонентного ХТО прискорює дифузійні процеси і сприяє поширенню тонкодисперсних включень з тугоплавких боридів на велику глибину. Це забезпечує формування багатошарового комплексного покриття з унікальними властивостями.

Ключові слова: багатокомпонентне насичення, багатофазна мікроструктура, попередня деформаційна обробка, бориди, зносостійкість.

(Received March 13, 2020; in final version, April 15, 2020)

\section{INTRODUCTION}

The structure and properties of the surface layers of machine parts and tools have an important influence on their working capacity, since during exploitation it is the surface layers that are most intensively subjected to temperature-force and aggressive influences. In some cases, chemical-thermal treatment (CTT) is the only possible means of obtaining the required operational properties of not only the surface, but also product as a whole. Such properties can be achieved by creating a surface layer with a multiphase structure obtained as a result of multicomponent saturation. Multicomponent saturation with different elements makes it possible to create multilayer composite materials with unique properties [1-3]. The increased wear and corrosion resistance of the boron-molybdenum layer and the lower brittleness of the borontungsten layer are observed in comparison with the boron layer [4-6]. It is of interest to create coatings on the surface of iron-based alloys during CTT in a multicomponent mixture of three or more elements, as the least studied and not found in the literature, for example, boronmolybdenum-tungsten, boron-molybdenum-silicon. Therefore, the purpose of this work is a study of the structure and properties of a multicomponent diffusion layer obtained on steel as a result of joint saturation with boron and other elements (silicon, molybdenum, tungsten) in order to create a multilayer complex coating with increased hardening micromechanical characteristics that provide wear resistance in a wide temperature range $[7,8]$.

\section{EXPERIMENTAL AND THEORETICAL DETAILS}

Saturation is carried out in a powder medium with boron carbide $\mathrm{B}_{4} \mathrm{C}$, activators $\mathrm{KBF}_{4}, \mathrm{Na}_{2} \mathrm{CO}_{3}$, alloying additives $\mathrm{WO}_{3}, \mathrm{MoO}_{2}, \mathrm{Si}(0.1), \mathrm{SiO}$ at temperature of $1223 \mathrm{~K}$ for $t=4$ hours. As samples we used steel 40, 45. Some of the samples are pre-treated in electrolyte plasma obtained in an aqueous boron-containing electrolyte solution in the regime: $U=60-90 \mathrm{~V}, j=0.98-1.7 \mathrm{~A} / \mathrm{cm}^{2}, t=20 \mathrm{~min}[9,10]$; with a load under the press of 10 tons (when the weight acts on an area of $0.64-1 \mathrm{~cm}^{2}$ cor- 
responds to a pressure of $0.156-1 \mathrm{GPa}$ ), explosion treatment [11]. The intensity of linear wear is determined by the SMU-2 friction machine. The friction is carried out according to the scheme 'shaft-partial insert' at a load of $4 \mathrm{MPa}$, which corresponds to the middle of the load segment of constant friction, the sliding speed is $1.3 \mathrm{~m} / \mathrm{s}$, the duration of friction is 0.5 hours, the length of the path in the sum at friction is $10 \mathrm{~km}$, counter body is hardened steel 45 . Metallographic analysis of the obtained samples is performed using a microscope NEOPHOT-21 and microhardness PMT3. The calculation of the critical stress intensity factor of the first deformation mode $\left(K_{1 \mathrm{C}}\right)$ is carried out according to [12]. The identification of the phase components is performed by $\mathrm{X}$ ray diffractometer analysis on the DRON-2 diffractometer in iron radiation. The heat resistance is determined by increasing the mass of the sample relative to the surface unit (specific mass gain) after exposure for 40 hours at $1273 \mathrm{~K}$ in an air atmosphere.

\section{RESULTS AND DISCUSSION}

The microstructure of the diffusion layer, presented on Figs. 1-3, is obtained as a result of multicomponent saturation, including the diffusion of boron and alloying components into the surface of steel pretreated to deformation of various intensities (electrolyte plasma, pressing, and explosion).

The results of layer-by-layer X-ray diffraction analysis of the surface after saturation with boron, molybdenum, tungsten showed that, along with iron borides $\mathrm{FeB}, \mathrm{Fe}_{2} \mathrm{~B}$, there are $\mathrm{Mo}_{2} \mathrm{~B}, \delta-\mathrm{MoB}, \mathrm{W}_{2} \mathrm{~B}_{9}, \mathrm{WB}_{4}$,

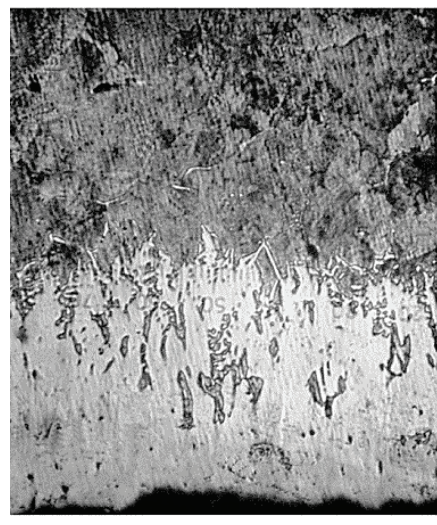

a

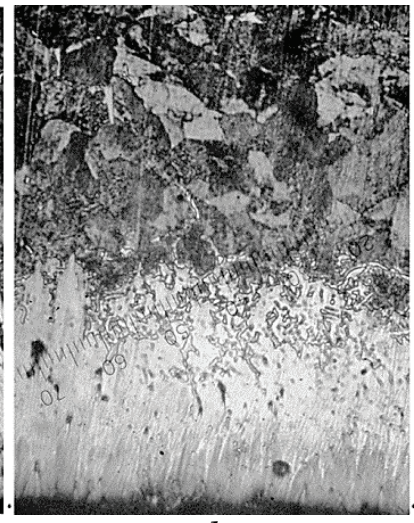

b

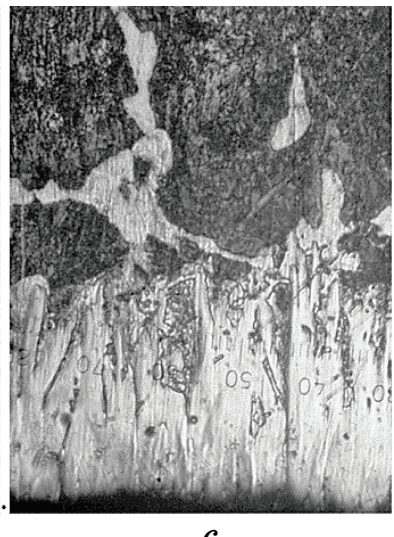

Fig. 1. Microstructure of diffusion layer at multicomponent saturation (boron-molybdenum-tungsten) of steel $40(\times 400)$ : without pre-treatment $(a)$, pre-treated in electrolyte plasma $(b)$, pre-treated under pressure $(c)$. 
$\beta$-WB, and $\mathrm{Fe}_{3} \mathrm{Mo}, \mathrm{Fe}_{2} \mathrm{~W}, \mathrm{Fe}_{7} \mathrm{~W}_{6}$, as well as ternary compounds $\mathrm{Fe}_{13} \mathrm{Mo}_{2} \mathrm{~B}_{5}, \mathrm{FeW}_{3} \mathrm{C}, \mathrm{Fe}_{3} \mathrm{~W}_{3} \mathrm{C}, \mathrm{Mo}_{2} \mathrm{BC}$. The depth of the obtained layer is $150 \pm 20$ microns depending on the treatment method.

Iron monoboride makes up about $30 \%$ of the total boride layer. The microhardness of the coating in the monoboride zone ranges from 33 to $21 \mathrm{GPa}$, and in the diboride zone from $17 \mathrm{GPa}$ to $15 \mathrm{GPa}$. The morphology of the boride layer does not have a pronounced needle shape of borides, as in the usual boronation of this steel grade. The space between the highly branched needles is filled with separate inclusions of borides (Fig. 1). According to [1], molybdenum and tungsten borides do not form when saturated with boron and molybdenum, as well as boron and tungsten.

However, with simultaneous saturation with boron, molybdenum, and tungsten, the X-ray diffraction data suggest that molybdenum, diffusing after boron, forms ternary compounds $\mathrm{Fe}_{2} \mathrm{MoB}_{4}$ and $\mathrm{Mo}_{2} \mathrm{BC}$ in the $\mathrm{Fe}_{2} \mathrm{~B}$ zone, and $\mathrm{Mo}_{2} \mathrm{~B}, \delta$-MoB are formed mainly in the $\mathrm{FeB}$ zone closer to the surface where the concentration of boron is quite high.

Here, mainly at the surface, tungsten borides are formed: $\mathrm{WO}_{3}+\mathrm{B}_{4} \mathrm{C}+\mathrm{C} \rightarrow \mathrm{W}_{2} \mathrm{~B}_{5}+\mathrm{CO}, \mathrm{W}_{2} \mathrm{~B}_{5}+2 \mathrm{~B}_{2} \mathrm{O}_{5} \leftrightarrow 2 \mathrm{WO}_{2}+9 \mathrm{~B}, \mathrm{~W}_{2} \mathrm{~B}_{5}+3 \mathrm{~B} \leftrightarrow$ $\leftrightarrow 2 \mathrm{WB}_{4}$.

The addition of tungsten to the saturating mixture according to the results of metallographic analysis increases the fragility of the low boron phase $\mathrm{Fe}_{2} \mathrm{~B}$ and the amount of high boron phase $\mathrm{FeB}$.

The results of layer-by-layer X-ray diffraction analysis of the surface after saturation with boron, molybdenum, and silicon showed that, along with iron borides $\mathrm{FeB}$ and $\mathrm{Fe}_{2} \mathrm{~B}$, there are phases, which are located as follows: the outer zone up to $200 \mu \mathrm{m}$ deep contains iron bo-

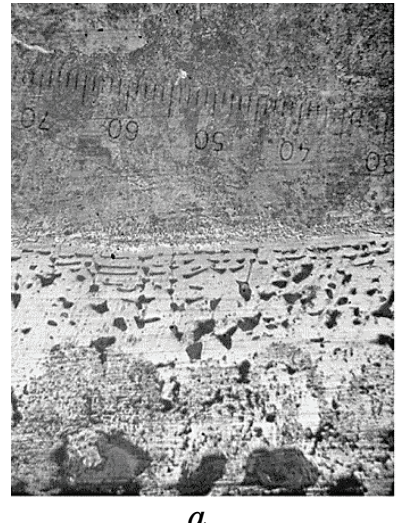

$a$

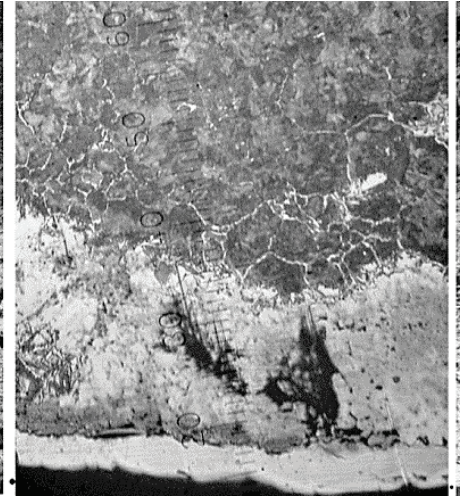

$b$

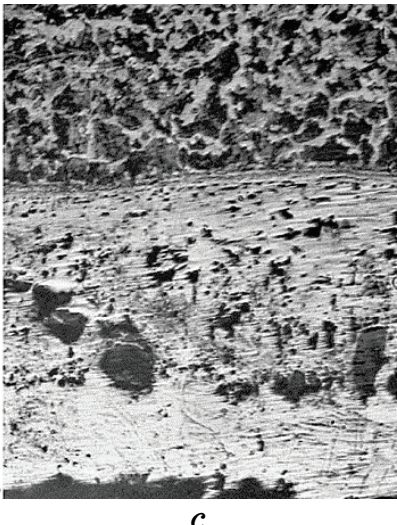

Fig. 2. Microstructure of diffusion layer at multicomponent saturation (boron-molybdenum-silicon) of steel $40(\times 50)$ : without pre-treatment $(a)$, pretreated in electrolyte plasma $(b)$, pre-treated by explosion [11] $(c)$. 
rides doped with silicon and molybdenum $\left(\mathrm{FeB}, \mathrm{Fe}_{2} \mathrm{~B}, \mathrm{Mo}_{2} \mathrm{FeB}_{4}, \mathrm{Fe}_{4} \mathrm{~B}_{2}\right.$, $\left.\mathrm{FeMo}_{2} \mathrm{~B}_{2}, \mathrm{Fe}_{3} \mathrm{SiB}_{2}, \mathrm{~B}(\mathrm{Fe}, \mathrm{Si})_{3}\right), \mathrm{Mo}_{2} \mathrm{~B}_{5}$, then goes the zone to a depth of 300-350 microns, consisting of solid inclusions (hardness 8-13 GPa) in the field with lower hardness (4-6 GPa) $\left(\mathrm{FeMo}_{2} \mathrm{~B}_{2}, \mathrm{Fe}_{7} \mathrm{Mo}_{3}, \mathrm{Fe}_{2} \mathrm{~B}\right.$, $\mathrm{Mo}_{2} \mathrm{~B}_{5}, \mathrm{Mo}_{5}(\mathrm{~B}, \mathrm{Si})_{3}, \mathrm{Fe}_{5} \mathrm{Si}_{3}, \mathrm{Fe}_{3} \mathrm{Si}, \mathrm{Fe}_{2} \mathrm{Si}_{0.4} \mathrm{~B}_{0.6}, \mathrm{Mo}_{5} \mathrm{Si}_{3}$. At the boundary with the base (Fig. 2) there is a zone with a thickness of $10-20 \mu \mathrm{m}$ with a hardness of $6.6 \mathrm{GPa}$, to which a light band with a thickness of 20$30 \mu \mathrm{m}$ with a microhardness of $3-4 \mathrm{GPa}$ is adjacent. In the formed diffusion layer there is also a redistribution of Mo and Si according to the principle of least action. At this stage of saturation, microinclusions are formed from iron compounds with diffusing components (double and triple phases), which are located mainly along the boundaries of the boride phase - iron monoboride and on the interphase boundaries. The alternation of solid and less solid zone contributes to the improvement of the micromechanical characteristics (Table 1), namely the reduction of micro-fragility, increase of the wear resistance and heat resistance of the coating. Moreover, the heat resistance of the coating is increased by $10 \%$ compared to [3] $\left(3 \mathrm{~g} / \mathrm{m}^{2}\right.$ against $\left.2.7 \mathrm{~g} / \mathrm{m}^{2}\right)$.

According to the results of metallographic analysis (Table 1), the pre-treatment of various intensities deformation on the steel samples affects the depth and micromechanical characteristics of the diffusion layer obtained after CTT in a multicomponent environment. The formed diffusion layer with a depth ranging from 300 to $450 \mu \mathrm{m}$ and sublayer with a structure characteristic of the concentration peritectic heterogeneity of $\mathrm{Fe}-\mathrm{C}-\mathrm{Si}-\mathrm{B}$ with the possible presence of Mo (Fig. 2) does not have clear boundaries. The layer contains inclusions whose microhardness is $15-16 \mathrm{GPa}$, and, in addition, a zone with a depth of

TABLE 1. The values of depth of diffusion layer $h$, microhardness $H_{\mu}$, resistance to brittle fracture $K_{1 \mathrm{C}}$, intensity of linear wear $I_{\mathrm{n}}$ depending on the type of steel 40 pre-treatment.

\begin{tabular}{|c|c|c|c|c|c|c|c|c|}
\hline \multirow[b]{2}{*}{ No. } & \multirow[b]{2}{*}{$\begin{array}{l}\text { Type of pre- } \\
\text { treatment }\end{array}$} & \multicolumn{2}{|c|}{$h, \pm 20 \mu \mathrm{m}$} & \multicolumn{2}{|c|}{$H_{\mu}, \mathrm{GPa}$} & \multicolumn{2}{|c|}{$K_{1 \mathrm{C}}, \mathrm{MPa} \cdot \mathrm{m}^{1 / 2}$} & \multirow[b]{2}{*}{$\begin{array}{c}I_{\mathrm{n}} \cdot 10^{-9} \\
\pm 0.01\end{array}$} \\
\hline & & $\begin{array}{l}\text { Diffu- } \\
\text { sion } \\
\text { layer }\end{array}$ & $\begin{array}{l}\text { Sub- } \\
\text { layers }\end{array}$ & $\begin{array}{c}\text { Diffu- } \\
\text { sion lay- } \\
\text { er }\end{array}$ & $\begin{array}{c}\text { Sub- } \\
\text { layers }\end{array}$ & $\begin{array}{l}\text { Diffu- } \\
\text { sion } \\
\text { layer }\end{array}$ & $\begin{array}{c}\text { Sub- } \\
\text { layers }\end{array}$ & \\
\hline 1 & & 70 & 2 & & & 6. & 6.6 & .2 \\
\hline 2 & $\begin{array}{c}\text { Loa } \\
\text { pr }\end{array}$ & $130-2$ & 60 & $\begin{array}{r}13- \\
(20-\end{array}$ & & $6.1-$ & 6 & 0 \\
\hline 3 & - & 1 & ) & $\begin{array}{c}13-16 \\
(20-23)\end{array}$ & & $6.0-$ & 6 & 0.26 \\
\hline 4 & $\begin{array}{l}\text { Explosion } \\
\text { deformatio }\end{array}$ & 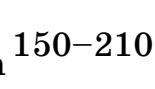 & & $\begin{array}{c}14-17 \\
(20-21)\end{array}$ & $\begin{array}{l}6-12 \\
(3-4)\end{array}$ & $6.2-$ & $.4-6.7$ & 0.18 \\
\hline
\end{tabular}


10-20 $\mu \mathrm{m}$ and a hardness of $6.6 \mathrm{GPa}$ is formed on the border with the base (Fig. 2, c). It should be noted that a similar structure is characteristic of all the presented methods for saturation of boron, molybdenum, silicon.

Pre-treatment of steel in an electrolyte plasma allowed to increase the depth of the diffusion layer, compared with untreated one, by $\mathbf{1 . 5}$ to 3 times. In addition, steel pre-treatment in electrolyte plasma, according to layer-by-layer X-ray diffraction analysis, promotes the diffusion of alloying elements over long distances with the formation of a greater number of finely dispersed refractory compounds, such as $\mathrm{Mo}_{2} \mathrm{~B}, \delta-\mathrm{MoB}, \mathrm{W}_{2} \mathrm{~B}_{9}, \mathrm{WB}_{4}, \beta-\mathrm{WB}, \mathrm{Fe}_{2} \mathrm{MoB}_{4}, \mathrm{Mo}_{2} \mathrm{BC}$. Due to this, the microhardness of the coating in the monoboride zone ranges from 33 to $21 \mathrm{GPa}$, which provides higher micromechanical characteristics of the steel surface.

Pre-treatment of steel in an electrolyte plasma allowed to increase the depth of the diffusion layer, compared with untreated one, by 1.5 to 3 times. In addition, steel pre-treatment in electrolyte plasma, according to layer-by-layer X-ray diffraction analysis, promotes the diffusion of alloying elements over long distances with the formation of a greater number of finely dispersed refractory compounds, such as $\mathrm{Mo}_{2} \mathrm{~B}, \delta-\mathrm{MoB}, \mathrm{W}_{2} \mathrm{~B}_{9}, \mathrm{WB}_{4}, \beta-\mathrm{WB}, \mathrm{Fe}_{2} \mathrm{MoB}_{4}, \mathrm{Mo}_{2} \mathrm{BC}$. Due to this, the microhardness of the coating in the monoboride zone ranges from 33 to $21 \mathrm{GPa}$, which provides higher micromechanical characteristics of the steel surface.

Pre-treatment by pressure promotes the formation of a diffusion
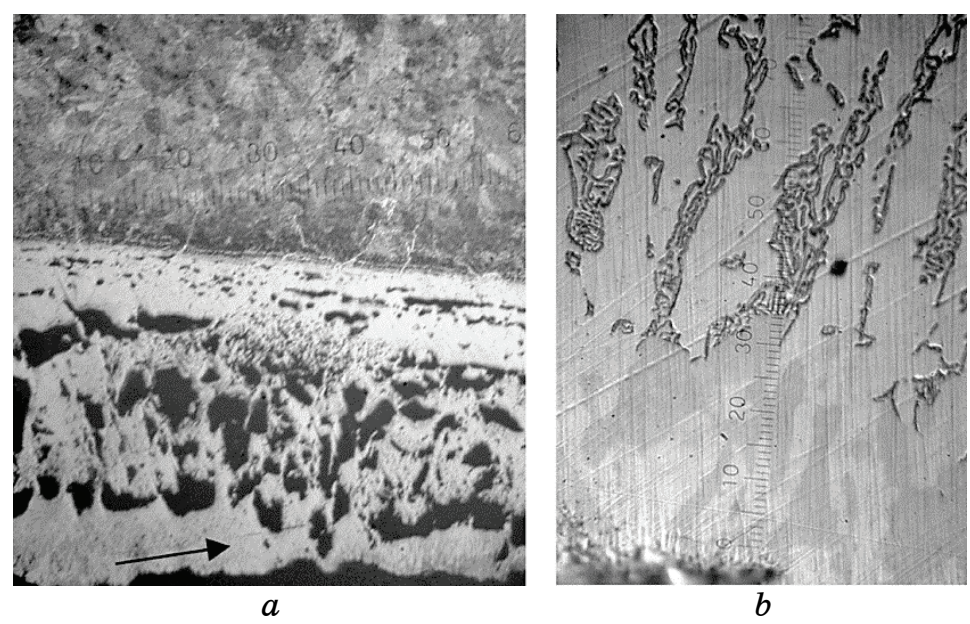

Fig. 3. Microstructure of diffusion layer at multicomponent saturation (boron-molybdenum-silicon) of steel 40: pre-treated by pressure with fragments at point 1 at magnification $(a), \times 1000(b)$. 
layer structure in many ways similar to that formed after pretreatment by explosion. For example, the presence of eutectoid (Fig. 3, $b$ ) is characteristic of both surface treatments. It should be noted the eutectoid is formed on the highly branched boride phases of FeB. The interruption of the continuity for the boride phase $\mathrm{FeB}$ and eutectoid formation to a greater degree is more inherent in samples with pretreatment by pressure (Fig. 3, b).

Explosion pre-treatment promotes to the formation of the diffusion layer with a maximum depth of $900-980 \mu \mathrm{m}$ and microhardness of 13$14 \mathrm{GPa}$. After pre-treatment by pressing, the diffusion layer is thinner on 100-150 $\mu \mathrm{m}$ and includes more soft structures (4 GPa). This difference shows that the intensity of deformations during surface pretreatment affects the diffusion rate and facilitates the movement of alloying elements over long distances with the formation of finely dispersed boride inclusions.

Compared with borosilication [2, 10], the boromolybdosilicated coating has a $20-22 \%$ greater thickness of the diffusion layer, high hardness and resistance to fragile destruction, less intensity of linear wear, increased heat resistance by $10 \%$ due to the doping of the boride layer with silicon and molybdenum and the formation of a sublayer having a multiphase composite structure from microcrystalline inclusions of compounds with Si and Mo, boron and iron.

\section{CONCLUSION}

Thus, the uses of the present mixture for multicomponent diffusion saturation allows obtaining the complex coating of modified boride layer and sublayer on the steel surface, which provides high hardness, resistance to fragile destruction, and wear resistance over a wide range of temperatures. Steel surface pre-treatment plays a significant role at saturation in the conditions of multicomponent CTT: it accelerates diffusion processes and promotes the distribution of finely dispersed inclusions from refractory compounds to a greater depth. This provides higher micromechanical characteristics of the steel surface compared to conventional boron saturation.

The processes of multicomponent saturation make it possible to form a multiphase structure of the surface layer with a set of useful properties. Moreover, such a combination of hardened product properties, which cannot be obtained by other methods, can be obtained by chemical-thermal treatment. In this case, CTT can be considered not as a specific operation of manufacturing a parts, but as a method of obtaining a fundamentally new structural material. Multicomponent saturation with different elements makes it possible to create multilayer composite materials with unique properties. 


\section{REFERENCES}

1. V. G. Zemskov and L. R. Kogan, Mnogokomponentnoe Diffuzionnoe Nasyshchenie Metallov i Splavov [Multicomponent Diffusion Saturation of Metals and Alloys] (Moscow: Metallurgiya: 1978) (in Russian).

2. L. S. Lyakhovich, L. G. Voroshnin, G. G. Panich, and E. D. Shcherbakov, Mnogokomponentnye Diffuzionnye Pokrytiya [Multicomponent Diffusion Coatings] (Minsk: Nauka i Tekhnika: 1974) (in Russian).

3. L. G. Voroshnin, S. D. Bashlak, B. B. Khina, and A. A. Shmatov, Mnogokomponentnye Diffuzionnye Karbidnye Pokrytiya na Zhelezouglerodistykh Splavakh [Multicomponent Diffusion Carbide Coatings on Iron-Carbon Steels] (Minsk: BNTU: 2007) (in Russian).

4. G. V. Borysyenok, L. A. Vasylyev, and L. G. Voroshnin, NTO Metallov $i$ Splavov [CTT of Metals and Alloys] (Moscow: Metallurgiya: 1981) (in Russian).

5. V. P. Glukhov, Boridnye Pokrytiya na Zheleze i Stalyakh [Boride Coatings on Iron and Steel] (Kyiv: Naukova Dumka, 1970) (in Russian).

6. V. F. Loskutov, V. H. Hyzhnyak, A. V. Byakova, and E. M. Grinenko, Mnohokomponentnye Pokrytiya na Stalyakh [Multicomponent Coatings on Steels] / Zashchytnye Pokrytiya na Metallakh [Protective Coatings on Metals] (Kyiv: Naukova Dumka: 1980), vol. 14 (in Russian).

7. A. N. Zavalyshyn, V. F. Loskutov, V. G. Permyakov, et al., Vliyanie Kompleksnogo Nasyshcheniya Borom i Perekhodnymi Metallami na Svoystva Staley i Chugunov [Influence of Complex Saturation with Boron and Transition Metals on the Properties of Cast Irons] (Kyiv: Naukova Dumka: 1977), vol. 11 (in Russian).

8. E. M. Grinenko and V. F. Loskutov, Vestnik Kievskogo Politekhnicheskogo Instituta, No. 25: 94 (1988) (in Russian).

9. L. I. Fedorenkova, N. Y. Filonenko, and I. M. Spyrydonova, Sposib Obrobky Stalevykh Vyrobiv [The Method of Treatment Steel Products], Patent of Ukraine No. 990119 (2012) (in Ukrainian).

10. L. I. Fedorenkova, Visnyk DNU. Fizyka. Radioelektronika, No. 12: 104 (2007) (in Ukrainian).

11. I. M. Spyrydonova and K. L. Dorogan, Zbirnyk Naukovykh Pratc FMMN, 2: 443 (2009).

12. N. V. Novikov, S. N. Dub, and S. I. Bulychev, Zavodskaya Laboratoriya, No. 7: 60 (1988) (in Russian). 